\title{
Mosquito breeding sites: distribution and relative abundance of species in the Jos Plateau, Nigeria
}

\author{
Greg. I. Anyanwu ${ }^{1)}$ and Moses O. E. Iwuala ${ }^{2)}$ \\ ${ }^{1)}$ Department of Zoology, University of Jos, P.M.B. 2084, Jos, Nigeria \\ ${ }^{2)}$ Department of Biological Sciences, Federal University of Technology, Owerri, Nigeria
}

(Received: 6 January 1998; Accepted: 31 May 1999)

\begin{abstract}
Key words: mosquito breeding sites, species distribution, abundance, Jos Plateau, Nigeria
\end{abstract}

\begin{abstract}
A 12-month bimonthly outdoor inspection of domestic water receptacles for immature mosquito breeding in the Jos area of Nigeria revealed a highly significant difference $(P<0.001)$ in mosquito abundance between the rural, semi-urban and urban centres and Culex quinquefasciatus and Aedes aegypti predominated in the samples. The high mosquito abundance in Jos urban and Bukuru during DecemberFebruary appeared to follow the seasonal rainfall pattern. Of all receptacles surveyed, plastic jars showed the least attraction for mosquito activity whereas clay/earthenware pots and metal cans were the favoured breeding units. The public health implications and mosquito breeding around human homes is discussed.
\end{abstract}

\section{INTRODUCTION}

Jos in central Nigeria is a clearly defined highland lying about $1800 \mathrm{~m}$ above sea level and situated between $10^{\circ} 30^{\prime}-09^{\circ} 00^{\prime}$ $\mathrm{N}$ and $09^{\circ} 30^{\prime}-08^{\circ} 30^{\prime} \mathrm{E}$. Annual temperatures are average $21-24^{\circ} \mathrm{C}$ especially at night. Very occasionally ground temperatures drop to below freezing point. The area experiences three marked seasons in the year: cold dry (November-February), hot dry (March-May) and rainy (JuneOctober).

The vegetation is mostly savannah with grassland and the rocky and undulating nature of the soil provides good drainage. Extensive tin mining and other mineral prospecting activities in the Jos area have given rise to characteristic depressions and excavations which afford breeding ground for mosquitoes. This survey was undertaken in view of the fact the information on mosquito activity in the Jos Plateau is few and limited to adults of

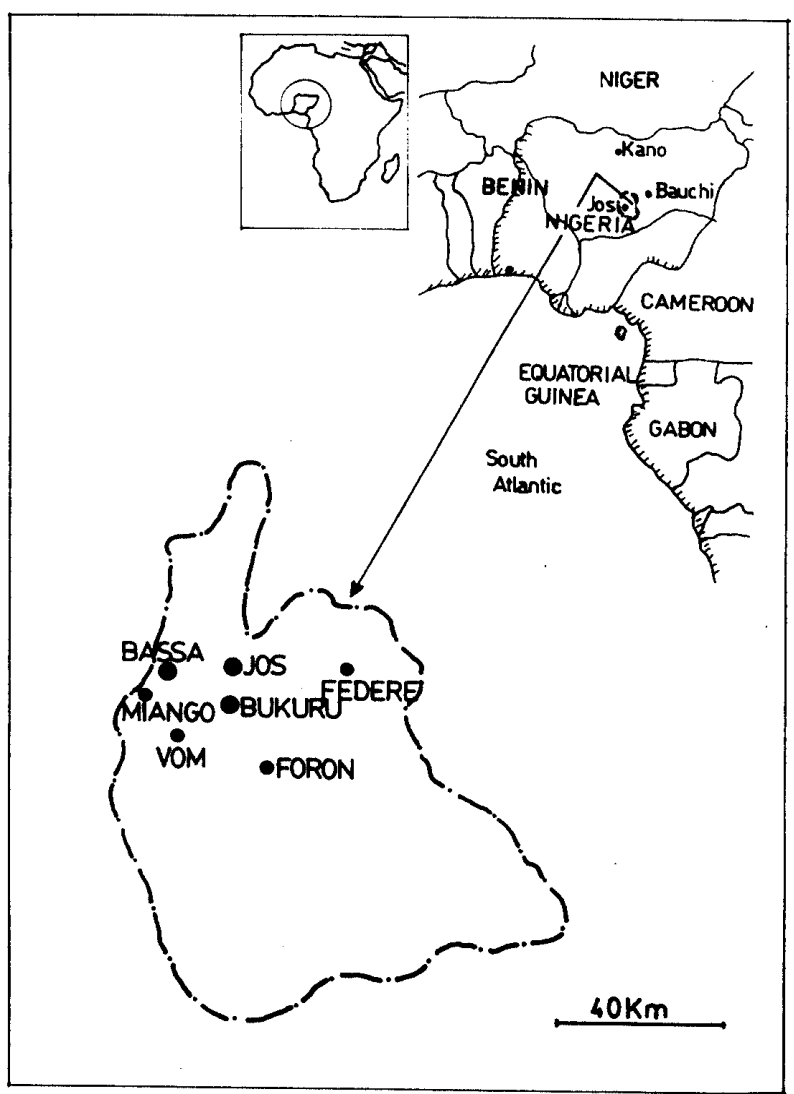

Fig. 1. Jos, Nigeria showing the sampling stations. 
Aedes (Stegomyia) species, the possible vectors of virus responsible for the 1969 Jos Yellow fever epidemic which affected 307 people out of which 116 were known to have died (Lee and Moore, 1972; Lee, 1979). There is an ongoing campaign on environmental cleanliness in Nigeria and hence we decided to investigate the possible contribution of the more common water receptacles to mosquito breeding activity and the maintenance of the disease cycle around human homes. The study was conducted in the Jos metropolis and the adjoining communities: 2 semiurban centres, Bukuru and Vom and 4 rural communities: Federe, Foron, Miango and Bassa (see map Fig 1).

\section{Materials And Methods}

Over a 12 month period, bi-monthly outdoor inspection was carried out on randomly selected premises in the designated areas (50 of the rural areas and 100 of the semi-urban and urban centres). During each visit, small water containers/receptacles were sampled for mosquito developmental stages by making scoops with a soup spoon emptied into a measuring cylinder to make up 1 litre. The larger water holdings were sampled using 10 sweeps of a pond net $(8 \mathrm{~cm} \times 11 \mathrm{~cm})$ mounted on a wooden frame (Service, 1976).

The field samples collected in labelled perspex containers were returned to the laboratory where the mosquito immatures were counted and recorded. Larval identification was made under the compound microscope using keys adapted from Hopkins (1952) and Foote and Cook (1959).

The pupal collections were kept till emergence and identified as adults using dissecting microscope (BUSCH AND LOMB) having a point light source, with the aid of keys adapted from Edwards (1941) and Gillett $(1971,1972)$.

\section{RESUltS}

1. Number, range and distribution of species

In all, 35 species of mosquitoes were found during the survey viz thirteen species of Aedes, six of Anopheles, eleven of Culex, two and three each of Eretmapodites and Coquillettidia respectively (Table 1 ).

Although the number of species found in the different study sites was not significant, there was remarkable difference (ANOVA, $P<0.001$ ) in the actual mosquito number collected as well as the composition of each species. The rural areas provided greater variety of species than either the Jos urban or the other 2 semiurban centres, Bukuru and Vom.

\section{Relative abundance}

A highly significant difference (ANOVA, $P<0.001)$ in mosquito population was evident between the rural, semi-urban and urban locations.

Of all the study sites, immature mosquitoes were most abundant in Bassa and the Jos metropolis. Least numbers were recorded in Foron and Vom.

Culex and Aedes mosquitoes predominated in the samples while Eretmapodites species were rare. Aedes aegypti, An. gambiae, $C x$. annulioris, $C x$. decens, $C x$.quinquefasciatus, $C x$. tigripes and Coquillettidia aurites were found in all the survey areas. Culex horridus, Cx. poicilipes, Eretmapodites chrysogaster and Er. quinquevittatus were restricted to the rural areas. Yet other species such as Anopheles maculipennis or An. nili occurred only in the Semiurban (Table 1).

\section{Seasonal productivities/Comparative mosquito scores}

The number of mosquitoes collected appeared to be in consonance with the seasons of the year: with low numbers in March-April and December-February but a build up from May-June peaking in September-November (Fig 2). Surprisingly, 
Table 1. The number of mosquito immatures and species collected in the Jos area (March 1987-February 1988).

\begin{tabular}{|c|c|c|c|c|c|c|c|}
\hline \multirow{2}{*}{ Species } & \multicolumn{4}{|c|}{ Rural } & \multicolumn{2}{|c|}{ Semi-urban } & \multirow{2}{*}{$\frac{\text { Urban }}{\text { Jos }}$} \\
\hline & Federe & Bassa & Miango & Foron & Vom & Bukuru & \\
\hline \multicolumn{8}{|l|}{ Aedes } \\
\hline aegypti & 494 & 350 & 708 & 644 & 622 & 874 & 622 \\
\hline africanus & 31 & 18 & 5 & 25 & 2 & 0 & 0 \\
\hline apicoargenteus & 0 & 21 & 0 & 0 & 9 & 0 & 12 \\
\hline cumminsii & 33 & 0 & 9 & 0 & 11 & 9 & 1 \\
\hline deboeri & 0 & 4 & 0 & 0 & 0 & 0 & 0 \\
\hline domesticus & 3 & 2 & 0 & 3 & 0 & 22 & 0 \\
\hline haworthi & 0 & 0 & 4 & 52 & 0 & 0 & 5 \\
\hline luteocephalus & 0 & 30 & 0 & 10 & 0 & 0 & 43 \\
\hline metallicus & 18 & 0 & 72 & 12 & 2 & 0 & 0 \\
\hline quasiunvittatus & 0 & 4 & 0 & 0 & 0 & 0 & 0 \\
\hline simpsoni & 0 & 0 & 2 & 11 & 0 & 3 & 0 \\
\hline taylori & 35 & 8 & 0 & 29 & 0 & 25 & 84 \\
\hline vittatus & 25 & 28 & 23 & 135 & 0 & 13 & 36 \\
\hline \multicolumn{8}{|l|}{ Anopheles } \\
\hline coustani & 0 & 0 & 0 & 16 & 9 & 0 & 0 \\
\hline gambiae & 122 & 27 & 2 & 15 & 3 & 13 & 15 \\
\hline garnhami & 4 & 0 & 0 & 0 & 0 & 0 & 0 \\
\hline maculipennis & 0 & 0 & 0 & 0 & 0 & 7 & 0 \\
\hline nili & 0 & 0 & 0 & 2 & 0 & 0 & 2 \\
\hline rufipes & 0 & 0 & 0 & 5 & 0 & 0 & 0 \\
\hline \multicolumn{8}{|l|}{ Culex } \\
\hline annulioris & 297 & 812 & 205 & 164 & 153 & 164 & 269 \\
\hline decens & 92 & 115 & 52 & 59 & 86 & 506 & 124 \\
\hline duttoni & 36 & 50 & 22 & 37 & 23 & 0 & 0 \\
\hline ethiopicus & 3 & 1 & 4 & 0 & 0 & 0 & 0 \\
\hline horridus & 0 & 30 & 28 & 0 & 0 & 0 & 20 \\
\hline nebulosus & 0 & 0 & 234 & 19 & 0 & 103 & 191 \\
\hline perfidiosus & 0 & 0 & 8 & 0 & 0 & 0 & 0 \\
\hline quinquefasciatus & 772 & 2,290 & 922 & 532 & 238 & 1,486 & 2,228 \\
\hline poicilipes & 0 & 20 & 6 & 13 & 0 & 0 & 0 \\
\hline tigripes & 127 & 325 & 108 & 46 & 29 & 37 & 59 \\
\hline unvittatus & 14 & 0 & 0 & 0 & 0 & 0 & 0 \\
\hline \multicolumn{8}{|l|}{ Eretmapodites } \\
\hline chrysogaster & 4 & 6 & 0 & 0 & 0 & 0 & 0 \\
\hline quinquevittatus & 0 & 0 & 0 & 6 & 0 & 0 & 0 \\
\hline \multicolumn{8}{|l|}{ Coquillettidia } \\
\hline aurites & 9 & 14 & 4 & 6 & 23 & 20 & 13 \\
\hline maculipennis & 1 & 7 & 2 & 0 & 3 & 0 & 9 \\
\hline metallica & 0 & 15 & 0 & 2 & 5 & 0 & 12 \\
\hline Total & 2,120 & 4,177 & 2,420 & 1,843 & 1,218 & 3,282 & 3,745 \\
\hline
\end{tabular}

however, abnormally high numbers of larvae and pupae were collected in Jos and Bukuru in February due to unusual concentration in the few available backpools and other miscellaneous sources.

\section{Breeding site preferences}

Attractiveness/preference of breeding sites for mosquito oviposition is indicated from their relative mosquito numbers. For instance whereas only $0.77 \%$ of $A$ nopheles mosquitoes were found breeding in metal cans, $54 \%$ of Aedes sp. were found 


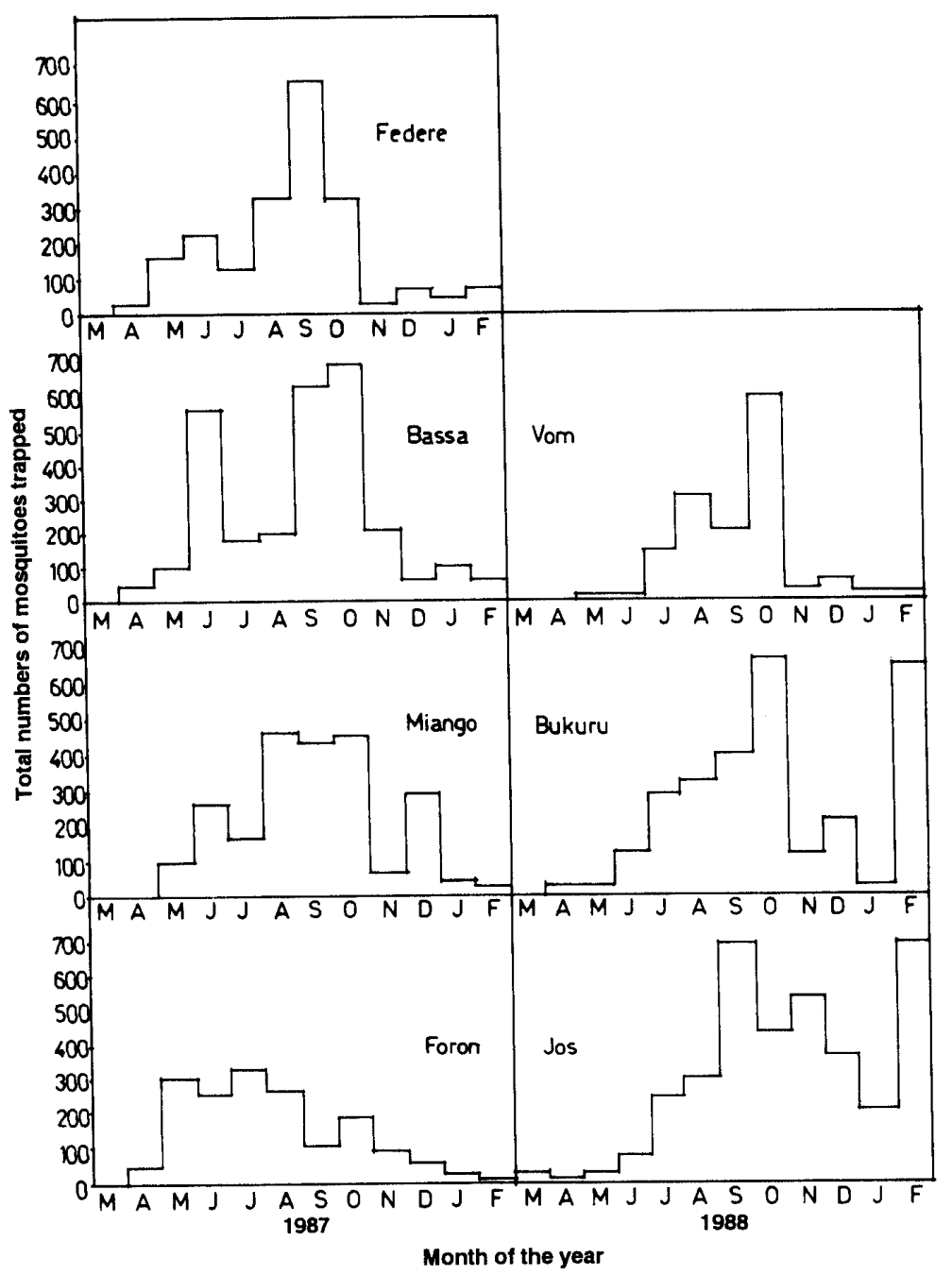

Fig. 2. Monthly totals of immature mosquitoes collected.

Table 2. Total numbers of immature mosquitoes collected from the different breeding habitats during the survey (March 1987-February 1988).

\begin{tabular}{|c|c|c|c|c|c|c|c|}
\hline Genera & $\begin{array}{c}\text { Water tanks, } \\
\text { Reservoirs, } \\
\text { Drums } \\
(2,005)^{*}\end{array}$ & $\begin{array}{c}\text { Clay/ } \\
\text { Earthenware } \\
\text { pots } \\
(6,842)\end{array}$ & $\begin{array}{c}\text { Metal } \\
\text { cans } \\
(8,880)\end{array}$ & $\begin{array}{c}\text { Plastic } \\
\text { containers } \\
(2,093)\end{array}$ & $\begin{array}{c}\text { Disused } \\
\text { motor } \\
\text { tyres } \\
(1,170)\end{array}$ & $\begin{array}{l}\text { Compound } \\
\text { wells } \\
(7,007)\end{array}$ & $\begin{array}{c}\text { Tree } \\
\text { holes, } \\
\text { etc. } \\
(201)\end{array}$ \\
\hline \multirow{2}{*}{ Anopheles } & 0 & 27 & 21 & 0 & 10 & 5 & 0 \\
\hline & $(0 \%)$ & $(0.33 \%)$ & $(0.77 \%)$ & $(0 \%)$ & $(0.61 \%)$ & $(0.29 \%)$ & $(0 \%)$ \\
\hline \multirow[t]{2}{*}{ Aedes } & 365 & 2,408 & 1,340 & 72 & 894 & 77 & 115 \\
\hline & $(26.74 \%)$ & $(29.43 \%)$ & $(48.99 \%)$ & $(42.11 \%)$ & $(54.25 \%)$ & $(4.51 \%)$ & $(45.28 \%)$ \\
\hline \multirow[t]{2}{*}{ Culex } & 983 & 5,668 & 1,354 & 84 & 729 & 1,622 & 133 \\
\hline & $(72.01 \%)$ & $(69.28 \%)$ & $(49.51 \%)$ & $(49.12 \%)$ & $(44.24 \%)$ & $(95.08 \%)$ & $(52.36 \%)$ \\
\hline \multirow{2}{*}{ Eretmapodites } & 0 & 4 & 0 & 6 & 0 & 0 & 0 \\
\hline & $(0 \%)$ & $(0.05 \%)$ & $(0 \%)$ & $(3.51 \%)$ & $(0 \%)$ & $(0 \%)$ & $(0 \%)$ \\
\hline \multirow[t]{2}{*}{ Coquillettidia } & 17 & 74 & 20 & 9 & 15 & 2 & 6 \\
\hline & $(1.25 \%)$ & $(0.90 \%)$ & $(0.73 \%)$ & $(5.26 \%)$ & $(0.91 \%)$ & $(0.12 \%)$ & $(2.36 \%)$ \\
\hline $\begin{array}{l}\text { Total number } \\
\text { of mosquitoes }\end{array}$ & 1,365 & 8,181 & 2,735 & 171 & 1,648 & 1,706 & 254 \\
\hline
\end{tabular}

* Numbers in parentheses indicate the total numbers of samples taken. 
Table 3. Summary of survey/inspection data on Aedes aegypti larva from the Jos area (March 1987February 1988).

\begin{tabular}{|c|c|c|c|c|c|c|c|c|}
\hline & \multicolumn{4}{|c|}{ Rural } & \multicolumn{2}{|c|}{ Semi-urban } & \multirow{2}{*}{$\frac{\text { Urban }}{\text { Jos }}$} & \multirow{2}{*}{$\begin{array}{c}\text { Total } \\
\text { All sites }\end{array}$} \\
\hline & Federe & Bassa & Miango & Foron & Vom & Bukuru & & \\
\hline No. of compounds inspected & 607 & 605 & 603 & 625 & 1,227 & 1,259 & 1,248 & 6,174 \\
\hline No. of positive compounds & 89 & 89 & 63 & 80 & 100 & 131 & 126 & 678 \\
\hline No. of containers checked & 3,427 & 3,313 & 2,740 & 2,487 & 2,622 & 3,474 & 2,945 & 21,008 \\
\hline No. of containers with water & 914 & 1,027 & 499 & 730 & 576 & 559 & 982 & 5,287 \\
\hline$\%$ of containers with water & 26.67 & 31.00 & 18.21 & 29.35 & 21.97 & 16.09 & 33.34 & 25.17 \\
\hline No. of positive containers & 107 & 98 & 67 & 78 & 96 & 122 & 113 & 681 \\
\hline House index* & 14.66 & 14.71 & 10.45 & 12.80 & 8.15 & 10.41 & 10.10 & 10.98 \\
\hline Container index* & 3.12 & 2.96 & 2.45 & 3.14 & 3.66 & 3.51 & 3.84 & 3.24 \\
\hline Breteau index* & 17.63 & 16.20 & 11.11 & 12.48 & 7.82 & 9.69 & 9.05 & 11.03 \\
\hline Average no. of containers/house & 5.65 & 5.48 & 4.54 & 3.98 & 2.14 & 2.76 & 2.36 & 3.40 \\
\hline Positive containers/positive house & 1.20 & 1.10 & 1.06 & 0.98 & 0.96 & 0.93 & 0.90 & 1.00 \\
\hline Average wet containers/house & 1.51 & 1.70 & 0.83 & 1.17 & 0.47 & 0.44 & 0.79 & 0.86 \\
\hline
\end{tabular}

* See Service (1976) for calculation

in disused motor tyres while $95 \%$ of Culex larvae were collected from compound wells (Table 2).

\section{Aedes aegypti larval indices}

A total of 6,174 premises were inspected for Ae aegypti between March and February of which $678(10.98 \%)$ were positive for Ae aegypti larvae or pupae (Table 3). Of a total of 21,008 containers checked, $5,287(25.17 \%)$ contained water while 681 (3.24\%) of these water receptacles actually contained immature Ae. aegypti mosquitoes.

The Breteau index was 11.03 positive containers per 100 houses inspected.

\section{Discussion}

This limited survey suggests that a variety of mosquitoes, some of public health importance, thrive in the Jos Plateau. Prominent in the samples include Ae. aegypti, Ae. vittatus, An. gambiae, $C x$. quinquefasciatus, $C x$. annulioris, $C x$. decens, and $C x$. tigripes. The number and distribution of species were not strikingly different between the localities surveyed but only in the actual composition and total numbers caught.

For instance, although more Ae. aegypti mosquitoes were caught in Bukuru and
Miango, there was no significant variation $(P>0.001)$ in the numbers from Foron, Vom and Jos town or those found in Federe and Bassa. Culex quinquefasciatus trapped in Bassa and Jos are comparable but there was greater variation between those caught at Vom and Bukuru or Federe and Jos/Bassa.

Seasonal mosquito productivities have been associated with proportion of containers positive for water and mosquito larvae (Table 3 ) and also the preferential ability of the different species to utilise the breeding units (Table 2). Most of the species peaked in September-October (Fig. 2) in consonance with the seasons. Culex quinquefasciatus was abundant in all breeding units while Ae. aegypti was mostly recovered from domestic water containers.

Containers varied in importance as breeding habitats: clay-earthenaware pots were the most productive and clearly favoured for Culex and Aedes mosquitoes while plastic cans were the least attractive although in general there was mosquito presence in one container type or another throughout the survey. The fact that most of the rural dwellers lacked good portable water makes clay pots and other domestic water stores of increased importance in the study areas as a whole. In 
such localities in addition, native pots, often employed in the fermentation of medicinal concoctions called "ruwan magani", serve as major habitats for culicine mosquito breeding activity mostly $C x$. quinquefasciatus.

Motor tyres abandoned at some obscure location in the premises or sometimes used by natives as wind checks on roof tops or to rim off poorly constructed compound wells rather become ideal and quiet breeding grounds for species like Ae. aeg$y p t i$ and $C x$. quinqefasciatius as was observed in the present investigation. "Rijiya" or compound wells did harbour tremendous numbers of immature mosquitoes particularly during the dry months when most other units lacked water.

Anopheles sp. e.g. An. gambiae were not so common during this survey. BruceChwatt (1957) observed that oviposition of An. gambiae occurred in villages near Enugu, eastern Nigeria. Service (1974) found $0.9-4 \%$ of mosquitoes in narrow necked pots in 6 villages in the Katsina area, north-central Nigeria, to be $A n$. gambiae but was doubtful whether oviposition occurred in the pots or in the nearby streams from which the water was fetched.

Culex quinquefasiatus was the dominant species in the survey sites (Table 1) as it was in the breeding units. It was not however among the species included by Boorman (1961) in his mosquito collections in Jos. By 1963, this species had been recorded in the Jos area (Service, 1963) and by 1970 had become fully established on the Jos Plateau (Lee and Moore, 1972) whereas $C x$. decens, $C x$. nebulosus and $C x$. duttoni Theobald were more numerous in domestic locations (Irving-Bell et al., 1987).

In this survey we found almost $11 \%$ of the houses positive for Ae. aegypti larva (Table 3 ). On average, only $3 \%$ of containers in the Jos locality had Ae. aegypti mosquito possibly indicating that peridomestic containers do not pose a public health risk in terms of mosquito breeding.
Elsewhere in Nigeria very high $A e$. aeg$y p t i$ larval indices have been recorded: Enugu, southern Nigeria (Hayes et al., 1973), Garki area of Kano, north-central Nigeria (Shidrawi et al., 1973) and in the Sudan savanna of north-western Nigeria (Service, 1974). In the north-western Nigeria area (Kano, Katsina, Gusau, BirninKebbi, Sokoto and Kontagora) Service (1974) reported Ae. aegypti larval indices of $11-53 \%$ from water pots and Ae. vittatus was found in some areas in up to $18 \%$ of the pots.

Our study suggests that a variety of containers and contrivances found in the vicinity of human homes in the Jos area are a major foci of mosquito breeding and this underscores their importance in maintaining and perpetuating the population of potential disease vectors for effective contact with their human or animal hosts for sustained disease maintenance.

Limited studies have been undertaken in parts of Nigeria on mosquito ecology and behaviour. This study on mosquito breeding is therefore relevant particularly in the on-going campaign on environmental sanitation and cleanliness by increasing our awareness to the public health danger posed by peri-domestic container breeding mosquitoes which tend to have been taken for granted in recent times.

\section{ACKnowledgements}

The authors gratefully acknowledge the assistance of Christopher Nden and Rimbin Mato, technical staff of the Zoology and Botany departments of the University of Jos, in communicating with the natives during the house to house visits.

We are equally thankful to the staff of the National Arbovirus and Vectors' Research Unit, Enugu for help with the identification of some of the mosquito specimens and to the Department of Zoology, University of Jos, Nigeria for allowing us the use of facilities for this study. 


\section{REFERENCES}

Boorman, J.P. T. (1961) Observations on the habits of mosquitoes of the Plateau Province, northern Nigeria with particular reference to Aedes (Stegomyia) vittatus Bigot. Bull. Entomol. Res., 52: 709725.

Bruce-Chwatt, L. J. (1957) An unusual epidemiology of malaria in south-eastern Nigeria. Trans. R. Soc. Trop. Med. Hyg., 51: 411-418.

Edwards, F. N. (1941) Mosquitoes of the Ethiopian Region, III. Culicine Adults and Pupae. pp. 245-336, Br. Mus. (Nat. Hist.), London.

Foote, R. H. and D. R. Cook (1959) Mosquitoes of Medical Importance. Agric. Handbk., No. 152, Agric. Res. Serv., U. S. Dept. Agric., Washington.

Gillett, J. D. (1971) Mosquitoes. 274 pp., Weidenfeld and Nicholson, London.

Gillett, J. D. (1972) Common African Mosquitoes and their Medical Importance. 103 pp., Heinemann Medical Books Ltd., London.

Hayes, R. O., R. D. Peterson and A. E. Anyanwu (1973) Preliminary survey for potential yellow fever vectors in the vicinity of Enugu, Nigeria. WHO/VBC/ 73.457 .

Hopkins, G. H. E. (1952) Mosquitoes of the Ethiopian Region I. Larval Bionomics of Mosquitoes and Tax- onomy of Culicine Larvae. pp. 8-355, Br. Mus. (Nat. Hist.), London.

Irving-Bell, R. J., E. I. Okoli, D. Y. Diyelong, E. O. Lyimo and O.C. Onyia (1987) Septic tank mosquitoes: competition between species in Jos, central Nigeria. Med. Vet. Entomol., 1: 243-250.

Lee, V.H. (1979) Further observations on the possible mosquito vectors (Diptera: Culicidae) of yellow fever of the Jos Plateau, Nigeria. Bull. Entomol. Res., 69: 255-265.

Lee, V. H. and D. L. Moore (1972) Vectors of the 1969 yellow fever epidemic of the Jos Plateau, Nigeria. Bull. Wld Hlth Org., 46: 669-673.

Service, M. W. (1963) The Ecology of Mosquitoes of the northern Guinea savanna of Nigeria. Bull. Entomol. Res., 56: 601-632.

Service, M. W. (1974) Survey of the relative prevalence of potential yellow fever vectors in northwest Nigeria. Bull. Wld Hlth Org., 50: 487-494.

Service, M. W. (1976) Mosquito Ecology: Field Sampling Methods, 583 pp., Applied Science Publishers, Essex.

Shidrawi, G. R., J. L. Clarke, J. R. Boulzaguet and J. S. Ashkar (1973) Culicine mosquitoes with particular reference to Aedes aegypti and their prevalence in a rural area of the African Sudan Savannah Garki district, Kano state, Nigeria. WHO/VBC/73.420. 